\title{
Kirja-arvosteluja—Book reviews
}

\author{
Kaufman, Terrence, Notes on the Decipherment of Tartessian as Celtic. Wa- \\ shington D.C.: Institute for the Study of Man. 2015. Journal of Indo-European \\ Studies Monograph Series No. 62. 526 pages. Hardcover price: \$102. ISBN \\ 978-0-9845383-6-2; Paperback price: \$68. ISBN 978-0-9845383-3-1.
}

Terrence Kaufman's Notes on the Decipherment of Tartessian as Celtic (NDTC) repre-sent an essentially positive appraisal of John Koch, Tartessian: Celtic in the south-west at the dawn of history (Aberystwyth, 2009; revised, expanded edition, Aberystwyth, 2013) (T1) and Tartessian 2: The inscription of Mesas do Castilinho; ro and the verbal complex; Preliminaries to historical phonology (Aberystwyth, 2011) (T2), in which Koch reads the 90-odd "Tartessian" inscriptions, probably mainly necrological in na-ture, ca. 750-450 BC, from south-west Iberia (Tartessos, Greek

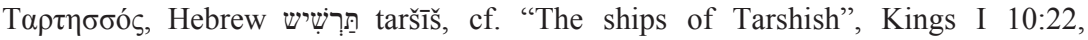
Ezekiel 27:12, etc.), in an alpha-syllabary (semi-syllabary: part alphabet, part syllabary, i.e. consonant + vowel) probably derived mainly from Phoenician, as the earliest extant form of Celtic. Koch builds on work by Juan A. Correa, Jürgen Untermann, and Jesús Rodríguez Ramos, bringing to bear a wide-ranging knowledge of various forms of Celtic as well as fami-liarity with current archaeological thinking on the relevant regions and horizons.

José Antonio Correa in 1989 and 1992 originally proposed that Tartessian was a Celtic language, but now regards it as unclassified. Jürgen Untermann in 1997 (Monumenta Linguarum Hispanicarum IV: Die tartessischen, keltiberischen und lusitanischen Inschriften) (MLH IV), on which Koch's work is heavily based, recognized that there might be Indo-European or specifically Celtic elements in the inscriptions. Francisco Villar, in a 2004 survey of Iberian Celtic, thought that the inscriptions might contain "an early form of Gaulish" within a non-Celtic and probably non-Indo-European matrix language. Jesús Rodríguez Ramos, on the other hand, thinks that the inscriptions are not Celtic, and probably not Indo-European. The possibilities thus range from, various authors: an unclassified non-Indo-European language, possibly containing some Celtic personal names, to John Koch: the earliest form of (Proto-)Celtic, and now Terrence Kaufman, who agrees.

Calling the language of the South-West Iberian inscriptions "Tartessian" is probably a misnomer, albeit one which is now unfortunately fairly well entrenched. A glance at 
a map of the locations of the inscriptions shows that they are heavily concentrated in the remote upland areas of southern Alentejo, just north of the Algarve in latter-day Portugal, and well to the west of the more fertile region centred on Huelva commonly recognized as having been the location of the fabled realm of Tartessos. As the local inhabitants of the area of the SW inscriptions were known to classical authors as the

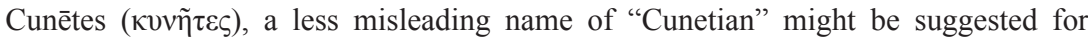
the language. The name Cunētes may be related to Welsh Cunedda, which would be fortunate if Tartessian/Cunetian does turn out to be Celtic.

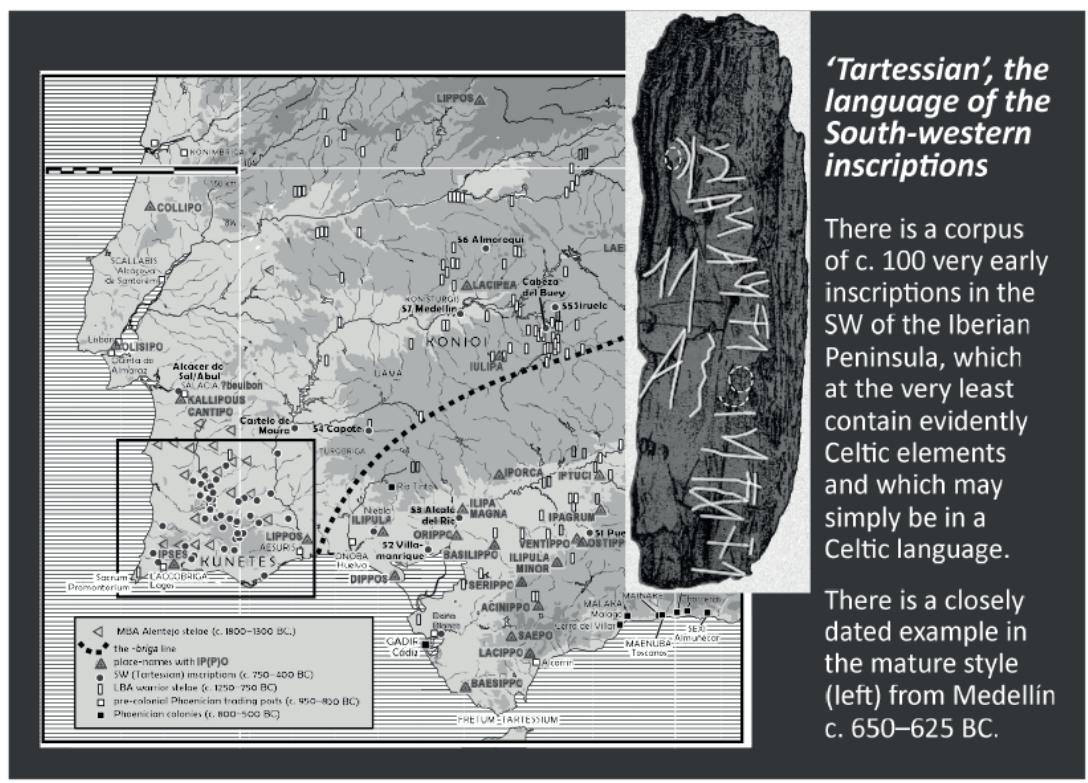

Source: John Koch: Celtic from the West (20/5). Used with permission. https://www. academia.edu//9895000/Celtic_from_the_West

If Tartessian (Cunetian) is fully Indo-European and Celtic, it begs the question of the place where Celtic first emerged and spread from: Hallstadt / La Tène, expanding towards both the Atlantic seaboard and Anatolia, the traditional version, or, in this radically new scenario, going from south-west Iberia to the north-east and north, with crucial implications for our understanding of the evolution of Indo-European as a whole.

Related to the Tartessian-as-Celtic proposal is the broader Celtic-from-the-West movement bringing together archaeologists, linguists and geneticists, which has resulted in three major conferences and related publications launched by Oxford archaeologist 


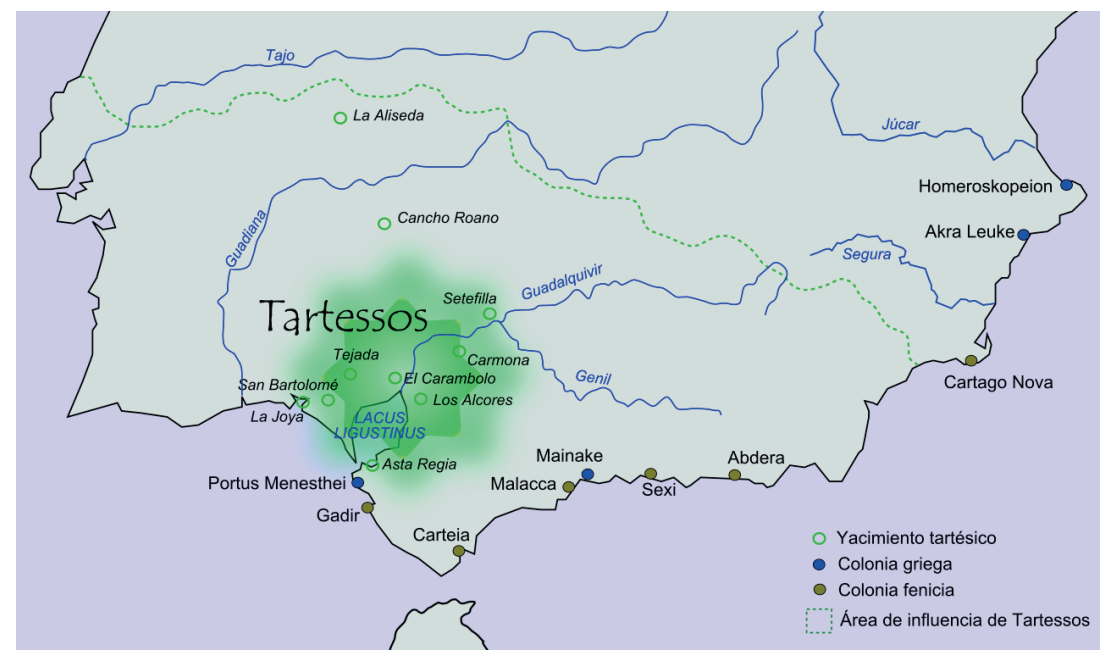

Source:Wikipedia: "Tartessian language”

Barry Cunliffe together with John Koch: Celtic from the West, Celtic from the West 2, and Celtic from the West 3 (Oxford, 2010, 2013, and 2016) (CfW1, 2, 3).

The relatively well, albeit not fully, understood South-West Iberian or Tartessian script or alpha-syllabary is:

\section{The South-western or 'Tartessian' Script}
a $\mathrm{A}$
e $\mathrm{O}$
i $M$
$0 \neq$
u 4
$\mathbf{b}^{\mathbf{a}} 3$
$\mathbf{b}^{\mathrm{e}} 9$
$\mathbf{b}^{\mathrm{i}} \uparrow$
$\mathbf{b}^{\circ} \square$
$\mathbf{b}^{\mathrm{u}}$ W
$\left.k^{a} g^{a} \bigwedge \quad k^{e} g^{e}\right\rangle \quad k^{i} g^{i} \Phi ? ? k^{\circ} g^{\circ} \boldsymbol{k ^ { u }} g^{u} \boxminus$
$t^{a} d^{a} X \quad t^{e} d^{e}=t^{i} d^{i}(1) ? t^{\circ} d^{0} \Delta \vee \quad t^{u} d^{u} \Delta$
$11 \mathrm{mM}$ mW $\mathrm{m}$ r9?0
$s \neq \quad s M \quad$ s

Source:John Koch: Celtic from the West (2015). Used with permission. https://www. academia.edu//9895000/Celtic_from_the_West. 


\begin{tabular}{|c|c|c|c|c|c|c|c|c|c|c|c|c|c|c|c|c|c|c|c|c|c|}
\hline & 4 & 1 & 4 & $\lambda$ & $\mathrm{I}$ & I & 日 & $\oplus$ & $z$ & 자 & $L$ & $y$ & $y$ & 手 & 0 & 7 & $r$ & $\Phi$ & 9 & W & + \\
\hline 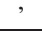 & $\mathrm{b}$ & $\mathrm{g}$ & $\mathrm{d}$ & $\mathrm{h}$ & W & $\mathrm{z}$ & h & $\underline{t}$ & $\mathrm{y}$ & $\mathrm{k}$ & 1 & $\mathrm{~m}$ & $\mathrm{n}$ & $\mathrm{s}$ & ‘ & $\mathrm{p}$ & $\underline{s}$ & $q$ & $\mathrm{r}$ & šs & $\mathrm{t}$ \\
\hline$?$ & $\mathrm{~b}$ & $\mathrm{~g}$ & $\mathrm{~d}$ & $\mathrm{~h}$ & $\mathrm{w}$ & $\mathrm{z}$ & $\hbar$ & $\mathrm{t}^{\varsigma}$ & $\mathrm{j}$ & $\mathrm{k}$ & 1 & $\mathrm{~m}$ & $\mathrm{n}$ & & ؟ & $\mathrm{p}$ & $\mathrm{s}^{\varsigma}$ & $\mathrm{q}$ & r & $\int$ & $\mathrm{t}$ \\
\hline
\end{tabular}

Tartessian shapes similar to Phoenician, transcription ( $k \sim g, t \sim d$ : closest to Phoenician value)

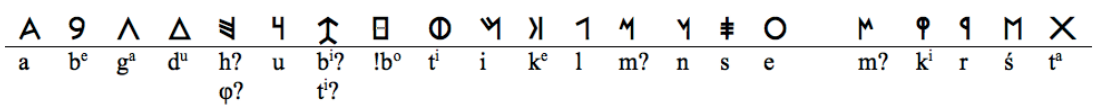

Stops (undifferentiated for voicing) have different signs for the consonant plus each of the five vowels, which are also redundantly written after the stop-plus-vowel sign (i.e. /ba/ is written $\mathbf{b}^{\mathbf{a}} \mathbf{a}$ ). The $\mathbf{b} / \mathbf{p}$ plus vowel signs shown above probably actually stand for $\mathbf{b}$ plus vowel only, $* / \mathrm{p} /$ being deemed absent from the phoneme inventorypossibly an areal feature, as absence of $/ \mathrm{p} /$ is also posited for Iberian and Celtiberian. The asymmetric signs, e.g. $\mathbf{i}, \mathbf{u}, \mathbf{k}^{\mathrm{e}}, \mathbf{b}^{\mathbf{a}}, \mathbf{b}^{\mathrm{e}}, \mathbf{r}, \mathbf{l}, \mathbf{n}$, etc. are usually reversed when used in the less common left-to-right order (both directions are found, as well as alternating boustrophedon; no word boundaries are indicated). The hoop with two horns $\boldsymbol{K}$ is

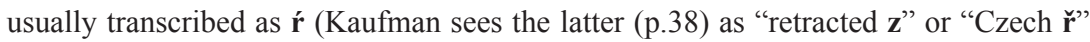
$\left.\left[\mathrm{z}_{\mathrm{Z}} \sim \mathrm{q} \sim \overline{\mathrm{r}}\right]\right)$.

Koch believes that the five different Tartessian symbols for each voiceundifferentiated stop, according to the following vowel, represent "consonant quality" (T1: 18, 138; T2: 140-42), and are thus analogous to the palatalization / velarization distinction in the Goedelic languages. That seems dubious on two grounds. (1) It is unheard of for a language to have five different phonological varieties of stops; two is quite common (palatalized /velarized, possibly three if one recognizes a neutral termneither palatalized nor velarized, as has been argued for Old Irish), but not five. (2) Irish palatalization or velarization are particularly marked before vowels of the opposite type, i.e. palatalized consonants before back vowels and velarized consonants before front vowels, whereas the five Tartessian variants almost always appear before the homorganic vowel, and that only; it is clearly not a distinction of an analogous type. An alternative explanation for the 15 stop graphemes (b-, T-, K- plus each of ${ }^{-a,-e,-i,-0,-u}$ ) might simply be that while it is easy to pronounce fricatives and sonorants without a following vowel by merely hissing, buzzing or humming, it is impossible to pronounce stops without a following vowel.

Absence of $/ \mathrm{p} /$ in non-Indo-European Iberian is said by some to account for the loss of / $\mathrm{p} /$ in (Iberian) Proto-Celtic by a substratal effect: Iberian-speakers shifting to 
Indo-European/Proto-Celtic were unable to pronounce $/ \mathrm{p} /$, thus explaining the loss of $/ \mathrm{p} /$ in Celtic.

Arabic, too, lacks /p/: Semitic/p-, - $\bar{p}-[-f-] /$ gives Arabic/f/ in all positions. Indeed, this gap in the phoneme inventory of Arabic is so strong that many Arabic-speakers not fluent in a European language have trouble pronouncing /p/. But the result is "In for a benny, in for a bound," not "In for a 'enny, in for a 'ound," as would be required by the theory outlined above.

One particular problem regarding the Tartessian script is the value of $\uparrow, \mathbf{b}^{\mathbf{i}}$ or $\mathbf{T}^{\mathrm{i}}$ ? Most scholars see it as $\mathbf{b}^{\mathbf{i}}$, and so do both Koch and Kaufman in some instances, but always as $\mathbf{T}^{\mathrm{i}}$ in the numerous endings in $\rightarrow N^{N} \boldsymbol{N}^{N}$, an "orthographic variation" of $\rightarrow \mathbb{N} \mathbb{O N}^{N}$, $-\mathbf{n T} \mathbf{i} \mathbf{i}$, read as $3 \mathrm{pl}$, crucial for the identification of Tartessian as Indo-European and Celtic. Clearly, more work needs to be done on resolving the remaining ambiguities of the Tartessian script.

It is also strange that voiced/voiceless pairs $\mathbf{d} / \mathbf{t}, \mathbf{g} / \mathbf{k}$ should be posited for Tartessian, yet the script only recognizes voice-undifferentiated stops $\mathbf{T}, \mathbf{K}$. Furthermore, the script does not have an unambiguous symbol for $\mathbf{m}$. Phoenician has all of the following separate symbols: $4 \mathbf{b} \sim 7 \mathbf{p}, \Delta \mathbf{d} \sim \mathbf{X} \mathbf{t} \sim \oplus \mathbf{t}, \mathbf{1} \mathbf{g} \sim \boldsymbol{X}_{\mathbf{r}} \mathbf{k} \sim \Phi \mathbf{q}, \mathbf{Y} \mathbf{w}$, and $\boldsymbol{M} \mathbf{m}$. So it is unclear as to why these phonemes should have caused a problem in the Tartessian script if Tartessian is indeed Celtic and the script was derived directly from Phoenician. Kaufman provides a plausible explanation in the idea (pp.43, 151-69) that the SW Iberian script was first developed from Phoenician for a Basque-related or Vasconic "Hipponic" language (numerous SW Iberian placenames in ip(p)o:(n), cf. Olisippo[na] 'Lisbon'); “There are so far 40 Turdetanian toponyms with strong or plausible explanations via Bask" (p.159); Turdetanian is applied to the cultural area following the collapse or disappearance of Tartessos. Proto-Basque is thought to have had only voiceless stops, and no $\mathbf{m}, \mathbf{w}$ or $\mathbf{y}$. Although the question then arises as to why no inscriptions in this putative predecessor language to Tartessian have ever been discovered.

Two immediate impressions on reading Koch on Tartessian as Celtic are, first, the lack of clarity on how he arrives at his conclusions: the constantly tentative phrases "could be, might well, possibly" are like so many leaps in the dark which magically shift to greater certainty without any more analytical ado. Secondly, and perhaps more damning, is a persistent and disturbing sense of anachronism: some of the Tartessian forms Koch analyses appear to be more eroded than their putative analogues in Old Irish or other attested forms of ancient Celtic, all of which are considerably younger than Tartessian (a thousand years younger in the case of Old Irish).

First off the review blocks was Tatyana Mikhailova, with a critical account of T1 in Voprosy jazykoznanija 2010/3: 140-45. Michael Koch wrote, in 2011, a critical review of T1 in Zeitschrift für celtische Philologie 58: 254-9.

On the other hand, Eric Hamp, in "The expansion of the Indo-European languages" (online pdf, 2013) includes, for the first time, Tartessian under Celtic, in an Indo- 
European language tree. This is the only endorsement of Tartessian as Celtic from a professional Celticist, and a very eminent one, albeit without any discussion of the question whatsoever. Hamp has written nothing to back up this significant endorsement.

Joseph Eska has written very critical reviews of T1 and T2, both in Kratylos 58 (2013), and of CfW2 in Bryn Mawr Classical Review (2013, online).

In 2014, a special issue (42/3-4) of the Journal of Indo-European Studies (JIES42) edited by Jim Mallory was published under the title The Indo-European-Tartessian Debate. The first article is nearly 100 pages long by John Koch expounding his view of the question, followed by critical articles by Joseph Eska (the Tartessian-as-Celtic enterprise), Miguel Valério (the south-western script), Blanca María Prósper (the classification of Tartessian as Celtic), and finally a spirited reply to his critics by John Koch. (Koch thus has $93+38=131$ pp. against his detractors: Eska -11 pp., Valério 28 pp., and Prósper 19 pp. = a mere 58 pp.).

Tatyana Mikhailova has written a further critical review of T1, T2, CfW1, 2, 3 in 2015 in Voprosy jazykovogo rodstva / Journal of Language Relationship 13/3: 257-79.

Dublin Institute for Advanced Studies (DIAS) Professor of Theoretical Physics, Werner Nahm, suggested in a talk on the subject at DIAS in October 2015 (p.c. David Stifter) that the proposals of Tartessian as Celtic had all the hallmarks of a new intellectual paradigm, which often triggered stiff resistance to begin with. It appears, nevertheless, that most of the audience remained unconvinced.

Finally, Joseph Eska published in 2017 a very critical review of NDTC in the Journal of Celtic Linguistics 18: 202-04. He writes: "It is not clear to me that TK [Terrence Kaufman] truly controls Celtic linguistics well or is knowledgeable about the Continental Celtic languages at all” (p. 203); disagrees (p. 203) with Kaufman's endorsement of Koch's analysis of Tartessian $\mathbf{t}^{\mathbf{e}} \mathbf{e}$, ro, ar, etc. as Celtic preverbs: "such brief phonological sequences can hardly said to be diagnostic of anything"; points to the weirdness of many of Kaufman's translations: "That any genre of inscription would include such statements seems highly improbable to me"; and concludes: "As is surely apparent, I find little of value in this volume. There may be some small amount of serious work to be done on Tartessian, but, to my mind, it is in the direction of seeking out whether there are viable comparisons to be made with Iberian morphological structure. This volume should never have made it into print."

Reviews of Tartessian and more generally Celtic from the West by Celtic linguists have thus been overwhelmingly critical and sceptical. Apart from NDTC, the only positive reactions have been by Eric Hamp (not a review, just acceptance, without any elaboration, that Tartessian could be Celtic) and Werner Nahm, not a professional Celticist.

On a related matter (of particular interest to me), for the first time we now have a plausible source for a Hamito-Semitic substrate to Celtic (if indeed Tartessian/Cunetian is Celtic and if Insular Celtic was indeed influenced by such a substrate). These are the 
Phoenician settlers who were neighbours of the Tartessians, and who continued to speak Phoenician there for the best part of a thousand years. But Graham Isaac has launched blistering attacks against the Hamito-Semitic substratum theory for Insular Celtic in Studia Celtica 38 (2004) and at a workshop on "The Celtic languages in contact" at the 2007 International Congress of Celtic Studies in Bonn (proceedings available online).

But now, Terrence Kaufman's NDTC endorses the reading of Tartessian as Celtic, and indeed claims to provide additional evidence in that direction. Kaufman's entry on the linguistics page of the University of Pittsburg reads: "PhD, University of California at Berkeley. Professor emeritus of linguistics and anthropology: Mesoamerican languages descriptive and historical, especially Mayan, Mixe-Zoquean, Zapotecan, and Nahua; language contact, dialectology, archaeological decipherment, lexicography, and cognitive anthropology; Indo-European, Germanic, history of English, and Romani." He claims a wide range of Indo-European languages, as well as Hebrew, Aramaic, and Phoenician, and has recently taken a special interest in Celtic. (As Eska casts doubt on Kaufman's ability in Celtic, some of Kaufman's remarks on Semitic, e.g. "Phoenician kapp, qOpp" (pp. 32-33; no evidence of gemination in those names in Phoenician) or "Quranic Arabic ... has VSO ... present-day Vernacular Arabic has SVO" (p. 129; Qur'ānic Arabic is probably dominantly VSO, but it is absolutely full of SVO too; most modern Arabic colloquials have both VSO and SVO_only Egyptian is strongly SVO) suggest a less than thorough mastery of that field.) Kaufman is co-author, with Sarah Thomason, of the influential Language Contact, Creolization and Genetic Linguistics (Berkeley, 1988).

Between 2006 and 2014 Kaufman compiled "Notes on the structure of Celtic languages and Celtic comparative grammar" $(446+159+150$ pp.) and a "Celtic etymological database" (ShoeBox etymological database with ca. 8,200 entries), both indicated in the bibliography (p. 515). In other words, he began working intensively on Celtic well before the publication of Koch's Tartessian (2009, 2nd ed. 2013) and Tartessian 2 (2011). However, neither Kaufman's notes on Celtic nor his etymological database, on both of which he draws heavily in NDTC, have been published, and are thus not available for the scrutiny of professional Celticists.

Kaufman's NDTC has the following main chapters and page numbers (showing the length of each chapter or section): 0 Introduction / preface / foreword, p. 1; 1 The Tartessian inscriptions, the Tartessian polity, and the Tartessian language, p. 3; 2 Tartessian is Celtic, p. 9; 3 The Tartessian writing system, p. 31; 4 Some methodological points on decipherment, p. 58; 5 Conclusions regarding the linguistic features of Tartessian, p. 59 (diachronic phonology, p. 60; Tartessian sound system, p. 73; lexical and morphological peculiarities, p. 79; verbs, p. 84; syntax, p. 118; nominals, p. 132); 6 The position of Tartessian within Celtic, p. 143; 7 Another "decipherment" of Tartessian as Celtic, p. 146; 8 Place names and personal names transmitted by Greeks and Romans, p. 148; 9 Non-Celtic material in Tartessian, p. 172; 10 Non-alpha-syllabic 
sources of Tartessian material, p. 175; 11 Names, p. 177; 12 Tartessian texts transcribed and analyzed, p. 179; 13 Tartessian vocabulary, p. 485; 14 Indo-European words for 'wolf' and 'fox', p. 506; 15 Abbreviations and conventions, p. 511; 16 Bibliography, p. 514; 17 Personal reflections on what led me to study Tartessian, pp. 519-26.

"I [Kaufman] start out by saying that Tartessian is resoundingly Celtic, and I bring to bear additional evidence so far not deployed by Koch" (p. 1). "Koch has discovered some of [the evidence that Tartessian is descended from proto-Celtic]; I have discovered additional evidence, and overall more than Koch" (p. 58). Kaufman describes a series of conversations held with Eric Hamp on 11, 12, 14, 28, and 30 August 2010 on whether or not Tartessian was Celtic (p. 9). Initially, Kaufman did not believe it was. The conversation on 14 August 2010 appears to have been the clincher: "I accept/acknowledge - as of 15 August 2010 - that Tartessian is a Celtic language. I have subsequently worked through all of Koch's data, plus three more inscriptions by Guerra in 2009." In other words, the passionate conviction that Tartessian is Celtic is suddenly in place, thanks to his friend and mentor, Eric Hamp, before he does any spadework. But he does not give us any details of that fateful conversation.

Recalling two Meso-American decipherments, Kaufman says: "The matches between the words read in Epi-Olmec texts and words reconstructed for proto-Sokean [Zapotec] are exact, not approximate. This is not the case with the hypothetical forms that Koch finds in the Tartessian inscriptions. This is a methodological and probably largely also a factual flaw in Koch's procedure" (p. 9). He also notes: "From the comparative Celtic perspective, the pronunciation of words suggested by Koch often seem more evolved than those of either Celtiberian or Gaulish" (p. 10) and "Koch's case overall is not presented with the systematicity and finesse that immediately convinces the reader, and several of his suggestions are demonstrably implausible and/or overshadowed by better hypotheses, such as those offered here" (p.10). "Two strategic missteps characterize Koch's search for Celtic parallels. If a similar form is found in other Celtic languages, they are assumed to be cognate, no matter how non-systematic the phonological 'equations' may be." (p. 10).

In the lengthy chapter on "Conclusions regarding linguistic features of Tartessian" (pp. $59-142$ ), we have a summary of Kaufman's view of proto-Celtic and how it relates to the Tartessian inscriptions. However, no sources whatsoever are given for Kaufman's information, and much of his speculation is fanciful, to say the least: for instance, for the presumed verb narke $e$ - (Koch: intransitive) 'remains fixed, unmoving, rests in peace' (T1: 111) / nazke- (Kaufman: transitive) 'bind, bind X in, bury, lay $\mathrm{X}$ in grave', Kaufman wonders (p.79): "Where would a preform like [nariKe-] or perhaps [naryVKe-] come from? For a while I was stumped. Then I said to myself that we might think of the root *rig-E- 'to bind'. How about *ad= rig-E- 'to bind'? [enadrig-] $>$ [enarrig-] $>$ [nazg-] 'to bind in'. For $<$ n- $>$, instead of *en= we might entertain the 
preverb $*$ ande $=$, but in J.1.1 $<$ n-az-ke-e- $>$ follows directly on $<$ ane $>$, which I take to represent *ande 'down, under',."

Kaufman notes (p. 69) that "[x]/k/ is not spelled out before /s, t/ .. < <anbati> *amb=a[x].t-i: 'servant' (Gs)...", one of the anachronistic features which makes Tartessian, if Celtic, look eroded in comparison with much later Celtic languages. For that, and other reasons: "Given the phonological history that lies behind Tartessian as we know it, there is no way that Tartessian is the ancestor of any other known Celtic language" (p. 72). He agrees (p. 110) with Koch's analysis of <ro-> as a marker of perfective aspect, as in Old Irish, and (pp. 110-19) with Koch's idea that Tartessian contains stacked preverbs, again on the pattern of Old Irish.

In a puzzling excursus (pp. 128-31), Kaufman opines that "Two features spread from Egyptian to European and Semitic languages ... the development of a definite article out of a preposed weak demonstrative and a shift [from VSO] to SVO word order." It is unclear how this, if confirmed, is relevant to what is known about Tartessian.

In the texts section of NDTC (pp. 179-484), each inscription includes (p. 179): [a] image of text (only sometimes, generally not as good as in Koch T1, T2); [b] Untermann serial number; [c] where images can be found; [d] how text is laid out; [e] state of preservation; [f] themes present; [g] genre; p.193: TO transcription of Tartessian orthography; TP assumed Tartessian pronunciation; UR* underlying representation in proto-Celtic garb with morpheme boundaries; MG morphemic gloss; LT literal translation; FT freer translation.

On the other hand, Koch T1 and T2 have better images of the inscription, but fewer levels of analysis: Untermann serial number; name, location found, museum conserved in; picture in many cases; (1) normalized Tartessian script (sorely lacking in NDTC); (2) transcription; (3) Celtic morphological equivalent; (4) translation. The fact that the levels of analysis do not correspond between T1, T2 on the one hand and NDTC on the other makes it somewhat laborious to compare the two authors.

Finally, there are a number of very unfortunate editorial problems with NDTC. Kaufman uses unwieldy and not always well-defined ASCII symbols and strings for transcription rather than conventional IPA symbols ("I will never use phonetic fonts in my published work" p. 511), and has other grating idiosyncracies, such as ' $\mathrm{xxx}^{\prime}$ ' for 'xxx', 'Bask' for 'Basque', 'Sapoteco' for 'Zapotec', 'Celtichood', etc. Pages vii-viii of the Table of Contents (which does not always correspond to the headings in the text!) appear again between pages 52 and 53 of the main text. Numerous references in the text are absent from the sketchy bibliography (which includes telegraphic notes after some entries - things we all do privately, but which few of us would wish to publish). Sometimes a full reference is given in the main text, but just as often it is merely an author (with or without date) who cannot be traced if missing from the bibliography. There is no full list of abbreviations. Some of the notes and headings are chatty, e.g. OK stuff; stuff that is unclear; stuff that is way wrong (Ch. 2 "Tartessian is Celtic"; 
no referenced justification for any of these comments). Numerous pages, especially in the texts and vocabulary sections, suddenly switch to horizontal Landscape layout, which could have been avoided by using smaller fonts or breaking up the texts of inscriptions into two or three lines instead having everything on a single line. This is very annoying, especially when trying to compare different pages which are not in the same orientation. It is surprising that the Institute for the Study of Man, whose flagship Journal of Indo-European Studies is a model of academic editing, should have agreed to publish unchanged a manuscript in such a sloppy and user-unfriendly state, especially at such a high price! It is not a pleasure to have or to work with. The volume is so shoddy that purchasers ought to write to the publishers to demand an $80 \%$ refund.

Specialists in the ancient Celtic languages are, with the sole exception of Eric Hamp, sceptical about the idea that Tartessian/Cunetian might be Celtic. Non-specialists, including many archaeologists of the relevant zones and horizons, theoretical physicist Professor Werner Nahm, and now decipherment specialist, but not a professional Celticist, Terrence Kaufman, are intrigued and sometimes well disposed. My personal curiosity has been dulled somewhat by the realization that if Tartessian/Cunetian does turn out to be Celtic, it is effectively more eroded than much later ancient Celtic languages (as also noted by Kaufman), and so it is highly unlikely that it could have transmitted substratal effects from Semitic Phoenician by some as yet unclarified mechanism, bypassing the rest of the European continent (where no Hamito-Semitic substratal traits have ever been found in Continental Celtic languages), to any of the Insular Celtic languages. In any case, with such a small and laconic corpus (which applies, relatively speaking, to both Tartessian/Cunetian and Phoenician), it is also highly unlikely that any syntactic substratal influence of Phoenician Semitic on Tartessian/Cunetian Celtic could be conclusively demonstrated.

Rather than bringing water to John Koch's mill, Kaufman's NDTC may actually have the effect of muddying the waters still further in the Tartessian/Cunetian-asCeltic debate. Any serious prospective investigator will need to read Koch's T1 and T2 together with Untermann's MLH IV, on which Koch's work is extensively based, and may now want to check each inscription against Kaufman's remarks, to the extent that they are coherent and have something new to say. However, it is clear that not all Kaufman's claims are entirely reliable. His most interesting suggestion is that of the SW Iberian script having been devised from the Phoenician script by speakers of a Proto-Basque language which he dubs "Hipponic". That would explain most of the quirks of the script, otherwise difficult to understand if borrowed directly by speakers of a "Celtic" Tartessian/Cunetian. It may even be the case that the language of the SW inscriptions is just such a "Hipponic" language and not Celtic or Indo-European at all; but that is not a possibility which Kaufman appears to have entertained.

In order to do justice to the Tartessian/Cunetian conundrum, one effectively needs to have expertise in Indo-European, ancient Celtic, Phoenician, Iberian, and Basque, 
a rather tall order. Incidentally, most Celticists are unaware of the sheer wealth of publications on pre-Roman Hispania; see, for instance, http:/ifc.dpz.es/publicaciones/ listado/categoria/9. It is a great pity that the vigorous debate among Celticists on Tartessian/Cunetian as Celtic does not appear otherwise to have kindled much interest among Peninsular specialists on the languages of pre-Roman Hispania.

Steve Hewitt

Östra Ämtervik, Värmland 
Ó Mainnín, M. B., Toner, G. (eds.)

Ulidia 4: Proceedings of the Fourth

International Conference on the Ulster Cycle of Tales. Dublin: Four Courts Press, 2017, 264 pp., ISBN 978-184682-631-3, 50€.

Ulster Cycle scholarship has advanced considerably since the days when Eugene O'Curry proposed, in his lectures on the sources for Irish history, that the corpus of early Irish tales was "strictly historical" in nature (O'Curry 1861: 239); or, when, almost a century later, O'Rahilly argued, in an unquestionable manner, that the main characters of the Cycle were in fact euhemerized deities (O'Rahilly 1946: 271). Nowadays, it seems to be generally accepted that any text represents an open "argumentative space" which can be analysed from various perspectives and "resists closed and finite interpretation" (Hollo 2004: 147-148). Depending on our subjective interpretation and on the methodology one employs, for example, structuralist, intertextual or feminist approaches, we discover yet another facet of a text which might have otherwise seemed to be familiar and thoroughly studied. "A pressing need to analyse the extant texts as literary works in their own right" was long ago voiced by Tomás Ó Cathasaigh (1984: 292), and was recently advocated by Ralph O'Connor in the introduction to his allembracing literary study of Togail Bruidne Da Derga (O'Connor 2013: 4). Although purely literary monographs are still a rarity in our field, the series of Proceedings of the International Conferences on the Ulster Cycle of Tales partly fill this gap.
Ulidia 4, edited by Mícheál B. Ó Mainnín and Gregory Toner, contains a selection of papers presented at the Fourth International Conference on the Ulster Cycle of Tales held in Queen's University, Belfast, on June 27-29, 2013. The programme of the conference included twenty-one papers, eleven of which were published in the present volume. The range of papers varies, and includes a discussion of manuscript contexts, literary critiques of the Ulster Cycle narratives, and historical analyses. The volume testifies to the fact that, despite the amount of scholarship already done, the Ulster Cycle still poses many questions which are to be elucidated and re-evaluated in the future.

The articles demonstrate the most recent discoveries in various fields of the discipline and are grouped thematically which facilitates the reading process as a whole. The opening essay by Fangzhe Qiu discusses the previously neglected connections between the Ulster tales and legal materials which feature characters or episodes from the narratives belonging to the Cycle. The evidence of legal tracts opens new perspectives for our understanding of how these tales were perceived and prioritised by the Irish literati themselves, without imposing our own assessments on the role of the tales within the tradition. It was indeed surprising to learn that "reference to the central tale, Táin Bó Cúailgne (TBC), is conspicuously absent" (pp. 10-11); or how the killing of Connlae by his father Cú Chulainn, known to us from Aided Énfhir Aife, was creatively reworked 
in $C I H$ 2127.19-2128.17 in order to illustrate a legal principle of unintentional kin-slaying (pp. 13-14).

Intertextual links and manuscript contexts are the subject of the following article by David Stifter, in which he addresses the collection of Ulster tales purportedly assembled in the now lost manuscript known as Cín Dromma Snechtai (CDS), while also assigning the monastery of Bangor as a possible location for the manuscript's provenance. Stifter also notices a strong "poetic undercurrent" in the compilation of $C D S$ - an idea which he illustrates with Fil and grian Glinne Ai, one of the poems once contained in the CDS. This sophisticated poem represents a "versified menu" at a banquet in which the "mundane subject matter" is obscured by means of "the most elaborate metaphors, kennings and circumlocutions, aggravated by deliberate deformations of words and playing with sounds" (p. 33). After such an appealing description of the composition, it is very regrettable that Stifter has not cited a single line of the text to give his readers a flavour of this undisputed chef-d'oeuvre of poetic mastery. The rationale is explained in a footnote, stating that "for reasons of space it is not possible to print it here." This decision, however, is disappointing since Meyer's edition of the poem has no translation (Meyer 1894: 46-48). I believe that one quatrain accompanied by interlinear glosses and a translation would not have made Stifter's article much longer, but it would have provided a curious reader with an example of how such a complicated poetic text might be approached and analysed. However, one may draw comfort from Stifter's intention to produce a new edition of the poem in the future (p. 32, fn. 30) and to discuss its poetic features elsewhere in due course (p. 34, fn. 34).

After we learned that space might be an issue, it was surprising to discover that the next article by Britta Irslinger occupies almost sixty pages (pp. 38-94). Irslinger's contribution is devoted to the comprehensive examination of the old and new etymologies for the name Medb. However, before we get to the main point on page 82 - that Medb might in fact mean "a ruler" and not "an intoxicating one" - we are presented with a detailed review of previous scholarship, starting with Stokes who was the first to propose the classical etymology in 1894, consideration of hieros gamos and sovereignty goddess in Irish and Welsh sources, discussion of Gaulish evidence and aśvamedha ritual, and other interesting but a bit overwhelming details that surround the etymology of 'Medb' like a network of paths branching off the main road. Irslinger's article is an example of thorough and brilliant scholarship, especially valuable for its discussion of Gaulish parallels, but the format of her contribution, in my opinion, would rather suit a booklet or a lecture (Erich Poppe's encyclopaedic Quiggin Memorial Lecture Of Cycles and other Critical Matters (2008) immediately comes to mind).

The next three articles by Tatyana A. Mikhailova, Joanne Findon and Gregory Toner deal with various compositional and thematic features of the Ulster tales. 
Notably, all three essays take, inter alia, Serglige Con Culainn as a case study, thereby illustrating how the same text can be interpreted differently, depending on a chosen methodological approach. Mikhailova studies the role of female introductory descriptions and comes to an interesting conclusion that the visual representation of a woman signalled for the audience that the character is otherworldly and ill-intentioned, while mortal heroines are described solely through their moral characteristics and virtues. Although this conclusion seems persuasive, in one of the examples which illustrates her point, Mikhailova argues that the compiler of the Táin "fails to give any physical description of Medb...[a] $\mathrm{t}$ the same time, Feidelm the seeress...is portrayed in a detailed and vivid manner (in both recensions of the saga)" (p. 96). One might remember, however, that Medb is in fact described in Recension I as a tall blonde woman with two golden birds on her shoulders (TBC I, 11. 32057; O'Rahilly 1976: 97). However, since the focus of Mikhailova's article is on the introductory descriptions, we might surmise that this depiction of Medb is irrelevant for her analysis as it does not introduce a new character.

Joanne Findon utilises one of the central concepts of Mieke Bal's narrative theory, namely, "focalisation"-which allows us to evaluate a narrative from a particular point of view-to consider the relationship dynamics between an Otherworld woman and her mortal partner in Serglige Con Culainn, Noinden Ulad and Tochmarc Becfhola. As Findon shows, such romances never have a happy ending primarily because mortal men repeatedly fail to appreciate their otherworldly wives, in which case the narrative function of these female characters is to challenge and to deconstruct the heroic image of the male protagonist. Gregory Toner offers yet another approach to the Serglige: he analyses the structure of the tale from the point of view of gender and social norms, describing the setting of the tale as an "abnormal realm" where the abnormality of the situation is a result of " $[t]$ he inversion of the power relationship between men and women" (p. 133). According to Toner, stylistically the tale is based on asymmetry, contradiction and binary oppositions which cross gender and world boundaries.

Sharon Arbuthnot continues her research on the meaning of gestures in the Ulster tales, based on the cases when a person touches another's chest or face. As she suggests, these symbolic gestures were aimed at threatening the person's honour and served as a means of self-protection for someone in a disadvantageous position. Martina Maher challenges the opinion that De Gabáil int Shída should be considered as a remscél to $T B C$ and argues that the tale is in fact a fully-fledged fore-tale since it provides the necessary precedent of verbal deceit, the narrative device which is actively used in $T B C$. One of the most interesting of Maher's ideas is the distinction between separate narrative universes which conditions the co-existence of various and sometimes contradicting versions of the same story. In this vein, different versions 
of the legend of Óengus taking the sid "could happily co-exist... as these were considered to be a part of two separate 'cycles', a Táin Bó Cuailnge cycle and a Tochmarc Étaine cycle” (p. 160).

The next essay, by Patricia Ronan and Gerold Schneider, will certainly be of interest to anyone who is even slightly familiar with Irish palaeography: Ronan and Schneider attempt to determine the identity of interpolator(s) $\mathrm{H}$ in Lebor na hUidre, with the help of stylometric analysis of the low-level linguistic features (functional words) in the texts attributed to H. Needless to say, Pandora's box was opened when Elizabeth Duncan published her ground-breaking article in which she differentiated scribe $\mathrm{H}$ into six distinct hands (Duncan 2015). Those who were lucky to be at Tionól 2017 will remember the talk of Dr Caoimhín Breatnach, who put forward very strong evidence against a multiplicity of scribes. However, the contribution of Ronan and Schneider neither confirms nor denies Duncan's theory. It looks like there were indeed a few scribes involved, but the correspondence of hands and texts is different, as, for instance, Comthóth Lóegaire (Duncan's H5) and Táin Bó Flidais (Duncan's H2) seem to be written (or even authored) by the same person (pp. 172, 173). In any way, this valuable research shows that the debate regarding $\mathrm{H}$ is far from being resolved.

The last two articles in the volume deal with the historiographical value and impact of the Ulster Cycle. Kay Muhr examines how Ulster politics might have influenced the geographical locations and genealogical connections mentioned in the tales. She argues that "intentional modifications of Ulster Cycle tales" ( $p$. 176) were made on behalf of the Uí Néill who were possibly attempting to "claim that the O'Neill kingship of Ulster had existed from prehistory" (p. 199). The last article, by Mícheál B. Ó Mainnín, revisits the phenomenon of Óenach Macha, referring to both the Assembly and the place-name. Ó Mainnín scrutinises various textual evidence including the Ulster Cycle tales, dindsenchas, Patrician sources, annalistic entries, and later saga material, and concludes that the name Óenach Macha may be relatively late in terms of its introduction and employment in the Irish literature. O Mainnín's conclusion agrees with recent discussion of the name Macha by Gregory Toner, who has argued that the name of Crunnchu's wife in Noinden Ulad might be a later interpolation (Toner 2010: 85).

Finally, one may notice minor editorial inaccuracies regarding the references throughout the volume. For instance, Qiu (p. 11, fn. 8) and Stifter (p. 24, fn. 8) refer to different articles by John Carey published in 1995 as "Carey 1995", but when we consult the bibliography, we find three articles of the same date i.e. attributed (1995a), (1995b) and (1995c) (p. 228). Likewise, Ruairí Ó hUiginn has two articles from the year 1992 (which are labelled 1992a and 1992b, p. 241) but the reference on p. 25 simply states "Ruairí Ó hUiginn (1992, 62)". On the other hand, Liam Breatnach's paper "Lawyers in early Ireland" is marked as (1990a) (p. 227), although this is the only 
quoted article by Professor Breatnach from the year 1990. Byrne's Irish Kings and High-Kings is referred to as "Byrne 1987" in Qiu's article (p. 21), but as "Byrne 1973" in Stifter's contribution ( $\mathrm{p}$. 24); while "Byrne 1987" does not appear in the Bibliography at all.

These minor incongruities, however, do not affect the quality of Ulidia 4 and do not lessen the enjoyment one gets from reading the articles which cover so many aspects of the Ulster Cycle scholarship. Although this volume contains fewer contributions than the previous three, this collection of essays could definitely be considered as klein aber fein. Ulidia 4 meets the high standards set by the three previous volumes and would appeal to many scholars with diverse academic interests.

\section{Bibliography}

Duncan, E. 2015. 'The palaeography of H in Lebor na hUidre'. In R. Ó hUiginn (ed.) Lebor na hUidre. Dublin: Royal Irish Academy, 29-52.

Hollo, K. 2004. 'Fingal Rónáin: The medieval Irish text as argumentative space'. In J. Carey, M. Herbert \& K. Murray (eds.) Cín Chille Cúile: Texts, Saints and Places: Essays in Honour of Pádraig Ó Riain. Aberystwyth: Celtic Studies Publications, 141149.

Meyer, K. 1894. Hibernica minora, being a Fragment of an Old-Irish Treatise on the Psalter. Oxford: Clarendon Press.

Ó Cathasaigh, T. 1984. 'Pagan survivals: the evidence of early Irish narrative'. In P. Ní Chatháin \& M. Richter (eds.) Irland und Europa: die Kirche im Frühmittelalter. Stuttgart: KlettCotta, 291-307.
O'Connor, R. 2013. The Destruction of Da Derga's Hostel: Kingship and Narrative Artistry in a Mediaeval Irish Saga. Oxford: Oxford University Press.

O'Curry, E. 1861. Lectures on the Manuscript Materials of Ancient Irish History, Delivered at the Catholic University of Ireland during the Sessions of 1855 and 1856. Dublin.

O’Rahilly, C. 1976. Táin bó Cúailnge: Recension I. Dublin: Dublin Institute for Advanced Studies.

O'Rahilly, T. F. 1946. Early Irish History and Mythology. Dublin: Dublin Institute for Advanced Studies.

Poppe, E. 2008. Of Cycles and other Critical Matters: Some Issues in Medieval Irish Literary History and Criticism. E. C. Quiggin Memorial Lectures 9. Cambridge: Department of Anglo-Saxon, Norse and Celtic, University of Cambridge.

Toner, G. 2010. 'Macha and the invention of myth'. Ériu 60, 81-109.

Ksenia Kudenko

Ulster University 
Constantine M.A. and É. Guillorel:

Miracles \& Murders: An Introductory Anthology of Breton Ballads. Oxford: Oxford University Press. 2017. 232 pp., ISBN 9780197266199, £55.

Miracles \& Murders: An Introductory Anthology of Breton Ballads is a valuable addition to the canon of ballad scholarship that is available in the English language. The expertise of the authors, Mary-Ann Constantine and Éva Guillorel, is evident in their introductory essay, which carefully places the ballad tradition of Brittany in its local, national, and international contexts; the close analysis which accompanies each of the song-texts is also of very high quality.

Without wishing to be overly Anglocentric, one of the great advantages of this work's availability is that it permits a degree of cross-cultural comparison to be carried out by those who are not proficient in the Breton language. Like the Englishlanguage ballads of the type collected by F.J. Child during the second half of the nineteenth century, the songs in this collection are generally composed of a combination of third-person narration and expository dialogue between characters. The stylistic features of narration in these ballads will also be well-known to those who are familiar with the Child-type ballad in English: the ballad is usually narrated in language which is sparse, and sometimes bleak, but which is occasionally illuminated by vivid flashes of detailsuch as "corpses on a beach being "eaten by yellow crabs"; a penitent soul huddled in a cold field "between the horses' feet"; a red-eyed fiend clinging to the burning spire of Quimper cathedral'-to which striking details the editors justifiably draw the reader's attention (p. 1).

In the context of the Celtic languages, there are also some parallels between the ballads in this collection and the Gaelicised versions of the Child-type ballad. The Breton ballad is not always entirely selfexplanatory and, as in Gaelic tradition, accompanying explanatory material is often necessary to fill in the gaps in the narrative-whereas the Child-type ballad in English is typically more of a selfcontained narrative. In truth, however, as the authors point out, there are not a great many parallel storylines which are apparent when Breton ballads and other ballad traditions are compared-although the authors carefully examine the Breton ballads' possible links with themes such as the Triads of medieval Welsh texts ( $p$. 45) and the shared traditions surrounding St Brigit and related figures (p. 71).

The songs and their accompanying essays shed light on some of the preoccupations of the Breton-speaking community over a period of several hundred years. The theme of religious faith looms large and, as the title indicates, miracles are a common feature of the ballads; the ballads' aforementioned use of vivid and precise detail serves, in the authors' felicitous phrase, as a means of 'materialising the miraculous' (p. 23; authors' italics). The community's great fears, including the plague (p. 73) and rabies (p. 77) are addressed, as are other fears which involve human agency: in common with Child-type ballads in 
English and their counterparts in Gaelic, the attention of the Breton ballad is often focused on close interpersonal relationships, and in particular on the cruelties that can be perpetrated within these relationships. Forced marriage, murder, rape, incest and infanticide are all represented within the pages of this anthology, and many of these themes appear repeatedly. This focus on terrible deeds is a matter of considerable interest; in this tradition, as in other traditions, it may well be the case that these cultural products exist as part of the process of dealing with such unpalatable realities.

One remarkable feature of these ballads is that tradition-bearers frequently proclaim them to be 'true' (p. 13)-although whether they are believed to be true in a literal sense, or whether they are true in the sense that they demonstrate certain fundamental truths about human relationships, is not entirely clear. I would like to have seen this idea of 'truth' teased out a little more - but perhaps the available evidence does not support any further interpretation. In any case, the authors' later phrase 'true in the ballad sense' (p. 93) is a helpful indicator of the fact that what is meant by 'truth' may vary in different contexts within the folk tradition.

The question of veracity is very skilfully handled by the authors in cases where the ballads appear to have some grounding in historical fact. Here we see various preoccupations being addressed by tradition-bearers-perhaps the most interesting of which is the use of the ballad as a counter-narrative to 'official' history (or, indeed, history as written by the victors) in contexts such as those of Breton nationalism (p. 94) and the French Revolution (pp. 189, 209). These ballads demonstrate the oral tradition's capacity for a remarkable tenacity in conserving ideas which may have been outside the mainstream of popular thought; we are indeed fortunate that so much of this material has been preserved by collectors and made available in this anthology.

Committing orally-transmitted material to print is a process which requires great sensitivity, and in this respect the authors have undoubtedly succeeded. The tradition-bearers from whom the material was collected are given their place; due attention is paid to alternative versions of songs and to performance contexts where known; the social forces and value-system which shaped the repertoire are carefully examined; and the inclusion of a $\mathrm{CD}$ with performances of some of the songs underlines the fact that this is primarily an oral tradition. Nonetheless, the authors caution against any misleading notion as to the 'purity' or inherent 'authenticity' of oral transmission (pp. 18-19) - a worthwhile reminder that channels of transmission can be complex and are often ultimately unknowable.

The analysis in this collection is wellwritten and accessible, and the book is beautifully produced. This publication will doubtless be of great interest to those who are interested in traditional song in any of its forms.

\section{Sorcha Nic Lochlainn \\ University College Cork}


Boyd, M.: The Four Branches of the Mabinogi. Peterborough: Broadview Press. 2017. Broadview Anthology of British Literature. 119 pp. ISBN 9781-55481-319-3. CA\$ 14.95 .

The Four Branches of the Mabinogi (Pedeir Keinc y Mabinogi) are a series of stories set in an ancient Wales where otherworldy kings and giants roamed, and where magic was possible. Loosely tied together by a shared formula at the close of three of the tales, and the sometimes blink-and-you-miss-it appearance of Pryderi (here translated as 'Carey', see below) in each branch, the Four Branches comprise what is perhaps the best-known body of Middle Welsh prose and one that is certainly a must-read for anyone interested in Welsh literature. Though the Four Branches are often translated with a number of other medieval Welsh tales-a collection known as the Mabinogion as popularized by their first English translator, Lady Charlotte Guest-they are presented on their own in this new translation by Matthieu Boyd. The tales are prefaced by a succinct introduction by Boyd which provides an overview of the history of the tales and their scholarly and popular reception, though it glosses over some of the larger academic debates such as those surrounding the date and authorship or nature of composition of the tales (pp. 7-11). A note on the translation is included (pp. 11-12), though it does not tell us from which version of the text Boyd translated. A map of Wales is also included (p. 13). An appendix titled 'In Context' (pp. 93-119) contains excerpts from Dafydd Jenkins' edition and translation of the Laws of Hywel Dda (Cyfraith Hywel; pp. 93-9), Rachel Bromwich's edition of Trioedd Ynys Prydein (The Welsh Triads; translated by Boyd, pp. 106-12), and Gerald of Wales' Descriptio Kambriae (The Description of Wales; translated by Boyd from the Latin, pp. 113-19). A selection of images taken from the pages of National Library of Wales Peniarth MS 28, a thirteenthcentury Welsh law manuscript, is also included (pp. 100-5).

The target audience and aim of this volume are made clear by Boyd in his note on the translation: 'Its primary purpose is to make the text accessible and engaging for twenty-first-century undergraduate readers in North America' (p. 11). It is unclear if the suggestion here is that other recent translations of the Four Branches, such as those included in Sioned Davies' 2007 translation The Mabinogion, are to some degree impenetrable or boring to undergraduates in North America in particular - a characterization of the students which I believe would be unfairor if this is rather an easy justification on the part of the publisher for a new translation of these texts on the (relative) heels of that work. No such justification should be necessary, however, as any new translation of the Four Branches will bring with it new interpretations and insights, and should generate interest in the tales and in Welsh literature more generally.

The excerpts contained in the appendix are one of the features of this volume which sets it apart from previous translations. Their inclusion provides useful context 
for the tales for those students who are unfamiliar with these texts and whose institutions may not have access to the editions from which they are taken. For those students who do have access to the texts, the hope is that the excerpts provided will prove interesting enough that they are encouraged to seek out the complete works for themselves. To this end, it is odd that no URL for the digital surrogate of National Library of Wales Peniarth MS 28 (www.library.wales/discover/digitalgallery/manuscripts/the-middle-ages/lawsof-hywel-dda/) was provided. It is possible that this decision was made on the basis that URLs are subject to change, though a general link to the website of the National Library of Wales - which is mentioned in the introduction to the selected images ( $\mathrm{p}$. 100)_would probably be more stable and certainly useful for students interested in medieval Welsh literature.

The effort to make the Four Branches 'accessible and engaging' by modernizing the language of the tales is another feature which separates this volume from previous translations. This effort was supported by Stacie Lents, a playwright who is credited with modernization assistance, and it comes largely in the form of the use of modern colloquial language. For example: 'fool around' for digrifwch (p. 20); 'killed time' for treulaw [trannoeth], diuyrru y dyd (p. 23) and A'r ulwydyn honno a dreulwys (p. 27); 'stud' for ceimat (p. 28); 'Ma'am' for gwreicda and 'buddy' for eneit ( $\mathrm{p}$. 35). Although some earlier translations of the tales of the Mabinogi have suffered from the use of archaic language and the romanticism of the Celtic Revival, the use of these modern colloquialisms - and anachronisms such as 'Manawydan \& Co.' (p. 60)-almost swings too far in the other direction; at times the language feels at odds with the setting, which as Boyd puts it is a 'primal past', 'once upon a time' (pp. 9-10).

Vulgarity was also introduced to add force to insults and exclamations, as Boyd explains of his translation of och as ' $\mathrm{Oh}$ shit' (p. 31, n. 1; p. 47, n. 3; 62). While it is unclear how Boyd reached his conclusion that och was 'the most forceful expression of surprise and dismay in the language' ( $p$. 31, n. 1), the English curse does reflect the gravity of some of the situations in which the utterers find themselves. The translation of direitwreic as 'bitch' (p. 80) and 'raging bitch' (p. 83) is more problematic. Boyd explains that direid, the first element of the compound used by Gwydion to describe his sister Aranrhod, "can mean "wicked," "nasty," or "out of control," but is also often used in a sexual sense, to mean "wanton" or "promiscuous" (p. 80, n. 3). The Geiriadur Prifysgol Cymru queries the meaning 'wanton', and provides an attestation from William Salesbury's A Dictionary in Englyshe and Welshe translating the word as 'shrewe', but there are not otherwise examples of the word in the entry which are particularly gendered or derogatory in the way Boyd suggests (s.v. diriaid). Though it is possible to see how the meaning of 'wicked woman' could be extended to 'bitch' in contemporary language, the justification is perhaps unsound and 'raging bitch' is surely an embellishment. 
At points, the translation is loose enough that it could cause confusion for any students seeking to compare the text to the original Welsh. For example, the exchange between Gwydion and Gilfaethwy near the start of the Fourth Branch is almost closer to interpretation than translation. The Welsh, as presented in Ian Hughes' edition of the text, reads in part:

Sef a wnaeth Guydyon y urawd, synnyeit dydgweith arnaw yn graf. 'A was,' heb ef, 'pa deryw ytti?' 'Paham?' heb ynteu. 'Beth a wely di arnaf i?' 'Gwelaf arnat', heb ef, 'colli dy bryt a'th liw, a pha deryw yti?' 'Arglwyd urawt,' heb ef, 'yr hynn a deryw ymi ny frwytha ymi y adef y nef.' 'Beth yw hynny, eneit?' heb ef (Hughes 2013, p. 1, 11. 17-21).

Boyd's translation of these lines is:

One day his brother Gwydion started staring at him. 'Hey, kid. What's happened to you?' 'What? Why?' said Gilfaethwy. 'Do I look weird?' 'You look all pale. What's wrong with you?' 'Noble brother,' said Gilfaethwy, 'there's no point in my explaining this to anyone.' 'Come on, what is it?' (p. 71).

While this translation conveys the sense of the interaction, it is not strictly faithful to the original text. A more literal translation would be:

This is what Gwydion his brother did, one day he looked at him closely. 'Oh lad,' he said, 'what happened to you?' 'Why?' he said, 'What do you see on me?' 'I see on you', he said, 'that you have lost your complexion and your color, and what has happened to you?' 'Lord brother,' he said, 'this thing which happened to me will not benefit me to confess to anyone' 'What is it, friend?', he said.

It is, of course, not necessary for translations to be literal, and non-literal translations can often be easier to read and may convey the meaning of the original as or more successfully than a literal translation. Certainly Boyd's translation is snappier than my more literal offering, but when the purpose of the translation is that it is to be used by students, diverging so far from the original may be unhelpful. Indeed, the interpretative nature of this translation has resulted in a rather confusing footnote on 'Noble brother' (Arglwyd urawt). The footnote reads:

Noble brother Gwydion calls his brother eneit, a term of endearment. But with this 'noble brother' or 'lord brother' (arglwyd urawt), Gilfaethwy becomes very stiff and formal, as though he's suddenly conscious of Goode [Math] overhearing (p. 71, n. 2).

A student unfamiliar with the Welsh language would be forgiven for at first thinking that 'Noble brother' was in fact a translation of eneit, before being told otherwise in the next sentence. Instead, the student is left hunting in the text for the translation of eneit, and as the footnote seems to imply that Gwydion's more familiar term of endearment precedes Gilfaethwy's formal address - at which point he becomes 'suddenly conscious' of being overheard - they might think that 'kid' was the translation of eneit. 'Kid', however, is a translation of gwas; eneit is in fact omitted entirely from Boyd's translation. A somewhat similar situation occurs again on the next page, where an 
out-of-place footnote commenting on a line of text which Boyd omitted from his translation but translated in the footnote itself causes unnecessary confusion ( $p$. 72, n. 1).

The most controversial innovation of this book is the translation of names. Pushback against the move may have been anticipated, as the note on the translation specifically addresses the surprise readers familiar with the Four Branches might experience upon seeing the English renderings, and explains that the decision was made firstly in an effort 'to make the names as meaningful in English as they would be to a Welsh audience...' (p. 11) and secondly because some of the names can be difficult for North Americans to pronounce (pp. 1112). Beginning with the second rationale, because some of the character names and the majority of placenames have not been translated, pronunciation will remain an issue for some students. A pronunciation guide such as is found in some previous translations may therefore have been more beneficial for students struggling with the Welsh language. It is notable that readers are directed to the Celtic Studies Association of North America's website (celtic.cmrs.ucla.edu/csana/ pronunciation.html) for pronunciation guidance (p. 12), although this resource only demonstrates how a selection of names from the First Branch sound when spoken by a native speaker of Welsh; it does not provide the tools for learning Welsh phonemes. It is also notable that the Celtic Studies Association of North America website remarks that being able to comfortably pronounce these names will make the tale more enjoyable. This is important because the names of characters in the Mabinogi are often the North American students' first introduction to Welsh and to Anglicize them is to deny these students an opportunity to become familiar with the language.

As for the first rationale, the assertion that English renderings of important Welsh names will be more meaningful to an English readership is unconvincing. While some names may carry 'plotrelevant meaning' (p. 11), it is difficult to see, for example, how 'Blondie Goodarm' is more impactful than Lleu Llaw Gyffes. Indeed, 'Blondie' in English is a diminutive with patronizing overtones while lleu ('light, bright', here as in 'fairhaired') is not a diminutive and does not have the same associations in Welsh. Similarly, Pwyll, with a Welsh meaning of 'deliberation, wisdom', becomes 'Sage'. This is not a bad parallel, but as an English name Sage is perhaps more likely to bring to mind the herb, along the lines of the names such as Heather, Rose or Daisy, than it is a wise man. Likewise, the rendering 'Carey' for Pryderi is unclear without explanation (p. 36, n. 1), perhaps because neither it nor the female homophone Carrie are associated with the verb 'to care' in English.

There are also problems and inconsistencies with some of the translated names. Boyd states in the note on the translation that the translated names are those which would have had 'a clear meaning in Middle Welsh' (p. 12). It is curious, then, that he chose to translate 
Llassar Llaes Gyfnewit as 'Llassar Firebrand Barter' while adding a footnote that says 'This name is difficult to interpret, but "Llassar Firebrand Barter" is a reasonable guess' (p. 43, n. 2). It is also unclear how this translation was arrived at: while 'fire' may be an element of the name, it would be found in llassar (Williams 1930, p. 179, n. 5; Ford 2000, p. 20, n. 105). However, Llassar may instead be related to blue enamel (Geiriadur Prifysgol Cymru s.v. llasar). While cyfnewid can mean 'trade, barter', llaes means 'loose, lax, negligent', producing an epithet 'Negligent Bargain' which may allude to the apparent trade Bendigeidfran makes of refuge in exchange for Llassar Llaes Gyfnewit's cauldron. Goewin, on the other hand, is not translated; a footnote explains that 'there is no clear meaning' of the name in that form (p. 70, n. 3). However, Geiriadur Prifysgol Cymru suggests the name may mean 'daring, bold' and includes an attestation from the Book of Taliesin (s.v. goiewin; see also Hughes 2013, pp. li-lii). Additionally, on two occasions names are translated not into English but into French: 'Blanche Crowe daughter of Ocean' (Branwen ferch Lŷr; p. 38, n. 1 and p. 39, n. 2) and 'Fleur' (Blodeuwedd; p. 84, n. 2). Although Blanche is used as a name in English, it is difficult to see how translating these names, at least in part, from Welsh into another foreign language is preferable to leaving them in their original forms. Furthermore, the use of Fleur for Blodeuwedd obscures the apparent distinction made in the manuscripts between Blodeuwedd's name, variously spelled in the manuscripts
Blodeuwed and Blodeued, and the common noun for "owl", consistently spelled blodeuwed (see Hughes 2013, p. 1xxxvi).

The worst English rendering of a name, however, is that of 'Busty' for Cigfa. When viewed through a modern lens, this name is obviously offensive. Nevertheless, as Boyd reminds readers in a footnote ( $p$. 56, n. 4 ), the society in which the tales of the Mabinogi take place is a patriarchal one, and if there were any indication that the name Cigfa would have carried the same weight for a medieval Welsh audience that 'Busty' carries for a modern one then perhaps the rendering would have been appropriate if distasteful. Yet it is unlikely that any element of Cigfa's name refers to her mammary glands, contrary to Boyd's explanation (p. 37, n. 1). Though unattributed, the suggestion of 'breast' seems to have come from Ifor Williams' note on the name in his edition of the Four Branches, where amongst a variety of possible meanings he discusses a proposal that cig is cognate with the Irish cich, 'breast' (Williams 1930, pp. 160-1, n. 24). That a meaning of 'breast' has been rejected, however, is implied by its omission from the entry on cig in the the Geiriadur Prifysgol Cymru (s.v. cig). The second element of the name, $-f a$, means 'place, plain', and was not analyzed by Williams in his note, nor does Boyd seek to explain it. A possible translation of 'Meat Place' is not included among the many euphemisms for a woman's bosom that I have ever encountered. Indeed, 'Meat Place' is such a nonsensical description of anything but a butcher's shop or a meat market (which is what cigfa came to mean 
by 1567; Geiriadur Prifysgol Cymru s.v. cigfa) that by Boyd's criteria Cigfa should have been left untranslated. Instead, it is as though the rendering of 'Busty' were intended to give female readers the feeling of being in a patriarchal society, as if we were unfamiliar in the era of \#MeToo.

In the introduction to her own translation of the Mabinogion, which remains standard, Sioned Davies notes that while Lady Charlotte Guest's original work presented the tales in both English and Welsh, revised editions omitted the Welsh and 'the text became appropriated by the culture of the English target language' (2007, pp. xxvii-xxviii, n. 11); it feels as though the rendering of names in English is the next step in this appropriation. The faults with this volume give the impression that it is expected that readers will be more interested in the content of the tales than the language from which they were translated. While this may be a fair assumption, especially given the likelihood that North American undergraduate students will not have had any prior exposure to Welsh, it seems counter-intuitive to shelter them from aspects of it such as pronunciation when the goal is ostensibly to get them interested in medieval Welsh literature and culture.

Setting aside these issues, however, efforts to expand the readership of medieval Welsh literature and to bring these tales into the curricula of English departments should be applauded, and this new translation of the Four Branches is, overall, an effective if not precise retelling which draws the reader in and keeps them interested. In addition to the assistance from a playwright and the breaking of the fourth wall ('Remember Rival?', p. 49), it is clear from a number of footnotes that Boyd is interested in the performative aspect of the tales and the mechanics of the narration (see, for example, the discussion above of Gilfaethwy stiffening in response to the perception of Math - 'offstage'overhearing his conversation; see also $\mathrm{p}$. 19 , n. 2 p. 48 , n. 3 ; p. 49 , n. 2 ; p. 3 , n. 1 ; p. 77 , n. $1 ;$ p. 87 , nn. 3-4). This interest is mirrored in the quick dialogues and colloquial language used to modernize the tales. Regardless of whether or not such updating was necessary to interest North American undergraduate students, this unintimidating volume of the Four Branches and the contextual material packaged with it is likely to make this an attractive resource for expanding reading lists for courses on British literature.

\section{Bibliography}

Davies, S., trans. 2007. The Mabinogion. Oxford: Oxford University Press.

Ford, P. K., ed. 2000. Manawydan uab Llyr. Belmont, MA: Ford \& Bailie.

Hughes, I., ed. 2013. Math uab Mathonwy: The Fourth Branch of the Mabinogi. Dublin: Dublin Institute for Advanced Studies.

Thomas, R. J., G. A. Bevan and P. J. Donovan, eds. 1967-2002. Geiriadur Prifysgol Cymru. Caerdydd: Gwasg Prifysgol Cymru.

Williams, I. Pedeir Keinc y Mabinogi. 1930. Caerdydd: Gwasg Prifysgol Cymru.

\author{
Myriah Williams \\ University of California, Berkeley
}

